\title{
1 Fast and easy disinfection of coronavirus-contaminated face masks using 2 ozone gas produced by a dielectric barrier discharge plasma generator
}

4 Jinyeop Lee ${ }^{1+}$, Cheolwoo Bong ${ }^{1+}$, Pan K. Bae ${ }^{2}$, Abdurhaman T. Abafogi ${ }^{1}$, Seung H. Baek ${ }^{1}$, Yong-Beom $5 \operatorname{Shin}^{2,3,4}$, Moon S. Bak ${ }^{1,5, *}$, and Sungsu Park ${ }^{1,5,6, *}$

6

$7 \quad{ }^{1}$ School of Mechanical Engineering, Sungkyunkwan University, Suw on 16419, Korea

$8{ }^{2}$ BioNano Health Guard Research Center (H-GUARD), Daejeon 34141, Korea

$9{ }^{3}$ Bionanotechnology Research Center, Korea Research Institute of Bioscience and Biotechnology 10 (KRIBB),

11 Daejeon 34141, Korea

$12{ }^{4}$ Department of bioengineering, KRIBB School, University of science and Technology (UST), Daejeon

13 34141,

14 Korea

$15{ }^{5}$ Biomedical Institute for Convergence at SKKU (BICS), Sungkyunkwan University, Suwon 16419, 16 Korea

$17{ }^{6}$ Institute of Quantum Biophysics (iQB), Sungkyunkwan University, Suwon 16419, Korea

+Each contributed equally to the work. 
medRxiv preprint doi: https://doi.org/10.1101/2020.04.26.20080317; this version posted May 5, 2020. The copyright holder for this preprint

(which was not certified by peer review) is the author/funder, who has granted medRxiv a license to display the preprint in perpetuity.

All rights reserved. No reuse allowed without permission.

39 Abstract

40 Face masks are one of the currently available options for preventing the transmission of the 41 severe acute respiratory syndrome coronavirus 2 (SARS-CoV-2), which has caused the 2019

42 pandemic. However, with the increasing demand for protection, face masks are becoming 43 limited in stock, and the concerned individuals and healthcare workers from many countries 44 are now facing the issue of the reuse of potentially contaminated masks. Although various 45 technologies already exist for the sterilization of medical equipment, most of them are not 46 applicable for eliminating virus from face masks. Thus, there is an urgent need to develop a 47 fast and easy method of disinfecting contaminated face masks. In this study, using a human 48 coronavirus (HCoV-229E) as a surrogate for SARS-CoV-2 contamination on face masks, we 49 show that the virus loses its infectivity to a human cell line (MRC-5) when exposed for a 50 short period of time ( $1 \mathrm{~min}$ ) to ozone gas produced by a dielectric barrier discharge plasma 51 generator. Scanning electron microscopy and particulate filtration efficiency (PFE) tests 52 revealed that there was no structural or functional deterioration observed in the face masks 53 even after they underwent excessive exposure to ozone (five 1-minute exposures). 54 Interestingly, for face masks exposed to ozone gas for $5 \mathrm{~min}$, the amplification of HCoV-229E 55 RNA by reverse transcription polymerase chain reaction suggested a loss of infectivity under 56 the effect of ozone, primarily owing to the damage caused to viral envelopes or envelope 57 proteins. Ozone gas is a strong oxidizing agent with the ability to kill viruses on hard-to58 reach surfaces, including the fabric structure of face masks. These results suggest that it may 59 be possible to rapidly disinfect contaminated face masks using a plasma generator in a well60 ventilated place.

61 Keyword: face mask, coronavirus, ozone gas, disinfection. 
medRxiv preprint doi: https://doi.org/10.1101/2020.04.26.20080317; this version posted May 5, 2020. The copyright holder for this preprint (which was not certified by peer review) is the author/funder, who has granted medRxiv a license to display the preprint in perpetuity.

All rights reserved. No reuse allowed without permission.

\section{Introduction}

72 Face masks are serving as one of the options for preventing severe acute respiratory 73 syndrome coronavirus 2 (SARS-CoV-2), which has caused the 2019 international pandemic of 74 the coronavirus disease. ${ }^{1}$ However, with increasing demands for protection, face masks are 75 becoming limited in stock; concerned individuals and healthcare workers from many 76 countries are now facing the issue of the reuse of potentially contaminated masks in many 77 countries. Thus, there is an urgent need to develop a fast and easy method of disinfecting 78 contaminated face masks. There already exist technologies for the sterilization of medical 79 equipment, including personal protective equipment (PPE); these technologies include 80 autoclave treatment, ethylene oxide gassing, ionized hydrogen peroxide fogging and 81 hydrogen peroxide vaporization. ${ }^{2}$ However, most of them are not practical for disinfecting 82 face masks with SARS-CoV-2. ${ }^{2}$ It was reported that ozone gas produced by plasma generators 83 can inactivate various types of viruses on different surfaces, including porous ones. ${ }^{3-6}$ Ozone 84 is a powerful oxidizing agent, but it does not linger. Its production, involving the use of 85 electricity and a normal atmosphere, is easy and inexpensive. However, it has not been 86 determined whether ozone gas can disinfect face masks contaminated with SARS-CoV-2 87 without compromising the filtration efficiency of the masks.

Here we show that a human coronavirus (HCoV-229E) ${ }^{7,8}$ as a surrogate for SARS-CoV-2 on face masks lost its infectivity to a human cell line (MRC-5) when exposed to gaseous ozone produced by a dielectric barrier discharge (DBD) plasma generator ${ }^{9}$ for a short time (1 min) (Figure 1). Neither structural nor functional deterioration of the face masks even with excessive exposures ( 5 times, 5 min per each time) to the ozone were observed by scanning electron microscopy (SEM) and a particulate filtration efficiency (PFE) test. Interestingly, RNA of HCoV-229E on the face masks by the ozone for 5 min was amplified by reverse transcription polymerase chain reaction (RT-PCR). This is the first demonstration of the potential of using ozone gas for disinfecting face masks contaminated with a coronavirus. 
medRxiv preprint doi: https://doi.org/10.1101/2020.04.26.20080317; this version posted May 5, 2020. The copyright holder for this preprint

(which was not certified by peer review) is the author/funder, who has granted medRxiv a license to display the preprint in perpetuity.

All rights reserved. No reuse allowed without permission.

High Voltage AC

98

99

100

101

102

103

104

105

106

107

108

109

110

111

Figure 1. A schematic diagram describing the disinfection of a face mask contaminated by a coronavirus using ozone produced by a DBD plasma generator. It consists of a high-voltage, high-frequency power supply and two electrodes separated by a $1 \mathrm{~mm}$-thick alumina dielectric barrier. Plasma was produced on the face of the device with the perforated electrode, along the rims of the holes.

\section{- RESULTS AND DISCUSSION}

Inhibitory effect of ozone gas on virus and bacteria on face masks. Among the numerous types of plasma generators, the dielectric barrier discharge (DBD) plasma generator is considered the most energy-efficient and cost-effective plasma generator for ozone production; it forms ozone through the dissociation of molecular oxygen $\left(\mathrm{O}_{2}\right)$ by collisions with excited electronic nitrogen populated by electron impacts and the ensuing combination between the atomic oxygen and $\mathrm{O}_{2}{ }^{9}$

When face masks, experimentally contaminated with a human coronavirus (HCoV$229 \mathrm{E})^{7,8}$ as a surrogate, were exposed to ozone gas (about $120 \mathrm{ppm}$ ) produced by the plasma generator for either 1 or $5 \mathrm{~min}$, no viable HCoV-22E was recovered from the face masks (Table 1). Corresponding untreated face masks showed the recovery of about 3 log units of tissue culture infective dose $50 \%\left(\log \mathrm{TCID}_{50}\right)$ per $\mathrm{mL}$ following $15 \mathrm{~min}$ of air drying. To the best of our knowledge, this is the first demonstration of the potential of using ozone 
medRxiv preprint doi: https://doi.org/10.1101/2020.04.26.20080317; this version posted May 5, 2020. The copyright holder for this preprint (which was not certified by peer review) is the author/funder, who has granted medRxiv a license to display the preprint in perpetuity.

All rights reserved. No reuse allowed without permission.

118 gas for disinfecting face masks contaminated with a coronavirus. Similar results were

119 obtained for face masks experimentally contaminated with either influenza $A$ virus $(H 1 N 1)^{10}$

120 (Table S1) or Gram-positive bacteria Staphylococcus aureus (Table S2 and Figure S1) when

121 exposed to ozone gas. These results suggest that virus and bacteria on face masks can be

122 inactivated by ozone gas at a concentration of about $120 \mathrm{ppm}$ within a short time (1-5 min).

Table 1. HCoV-229E titer recovered from contaminated face masks with and without 125 exposure to ozone gas.

\begin{tabular}{|c|c|}
\hline Treatment of face masks ${ }^{\mathrm{a}}$ contaminated with HCoV-229E & $\begin{array}{c}\text { Recovered virus }^{\mathrm{b}} \\
\left(\log \mathrm{TCID}_{50} \pm \text { S.D. }\right)\end{array}$ \\
\hline None & $3.0 \pm 0.2(\mathrm{n}=4)$ \\
\hline Ozone gas $\left(120 \mathrm{ppm}^{\mathrm{c}}, 1 \mathrm{~min}\right)$ & $0(\mathrm{n}=3)$ \\
\hline Ozone gas $(120 \mathrm{ppm}, 5 \mathrm{~min})$ & $0(\mathrm{n}=3)$ \\
\hline
\end{tabular}

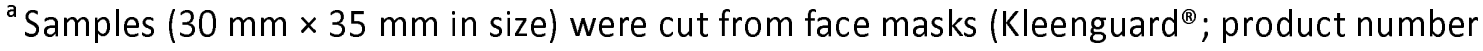

Y2-44015, Kimberly-Clark Worldwide, Inc., Irving, TX, USA) with 3-layers filtering. The front side was sprayed with about $250 \mu \mathrm{L}$ of HCoV-229E culture (about $4.5 \log \mathrm{TCID}_{50}$ per $\mathrm{mL}$ ) and dried at room temperature for $15 \mathrm{~min}$ in a biosafety cabinet before exposed to ozone gas.

${ }^{b}$ Virus particles on the samples were collected by washing the sample surface with $5 \mathrm{~mL}$ of PBS (phosphate buffered saline, pH 7.4) and measured using MRC-5 cells (ATCC, Bethesda, MD, USA). ${ }^{11}$

c The ozone concentrations produced by the DBD plasma generator were measured via UV absorption spectroscopy. ${ }^{12}$

$\mathrm{n}$ : sample number.

\section{Partial degradation of viral RNA by ozone gas}

138 To understand the mechanism underlying the viral inactivation of face masks by ozone gas, 139 the experimentally contaminated face masks (Kleenguard ${ }^{\circledR}$; product \# Y2-44015, Kimberly140 Clark Worldwide, Inc., Irving, TX, USA) - with and without exposure to ozone gas for 5 min141 were washed, and the washing solutions were assayed with the quantitative reverse 142 transcription polymerase chain reaction (qRT-PCR). ${ }^{13}$ Surprisingly, there was no significant 
medRxiv preprint doi: https://doi.org/10.1101/2020.04.26.20080317; this version posted May 5, 2020. The copyright holder for this preprint

(which was not certified by peer review) is the author/funder, who has granted medRxiv a license to display the preprint in perpetuity.

All rights reserved. No reuse allowed without permission.

143 difference ( $p>0.05$; student's t-test) in the amount of amplifiable RNAs between the 144 unexposed and exposed masks, indicating that the short exposure may not fully degrade the 145 viral RNA (Table 2). Similarly, the RNA of either H1N1 (Table S3) or S. aureus (Table S4) on the 146 face masks was not totally degraded by the exposure to ozone gas. These results suggest 147 that the loss of infectivity could be due to the damage to the viral envelope or envelope 148 proteins, resulting in failure of the virus to attach itself to host cells. ${ }^{14}$

149

150

Table 2: qRT-PCR of HCoV-229E in washing solutions obtained from contaminated face 151 masks with and without exposure to ozone gas.

\begin{tabular}{|c|c|}
\hline $\begin{array}{c}\text { Treatment of face masks contaminated } \\
\text { with HCoV-229E }\end{array}$ & $\begin{array}{c}\text { Ct value }^{\mathrm{a}} \\
\text { (mean } \pm \text { S.D.) }\end{array}$ \\
\hline None & $22.7 \pm 0.4(\mathrm{n}=6)$ \\
\hline Ozone gas (120 ppm, $5 \mathrm{~min})$ & $23.1 \pm 0.6(\mathrm{n}=6)$ \\
\hline
\end{tabular}

${ }^{a}$ cycle threshold $(\mathrm{Ct})$ is defined as the number of cycles required for the fluorescent signal to exceed the background signal level (threshold). n: sample number.

\section{No structural damage on the filter layer of face masks}

To test if the exposure of face masks (Kleenguard ${ }^{\circledR}$ ) to either plasma or ozone gas causes any damage to their filter layer, uncontaminated face masks were exposed to ozone gas for 5 min (five 1-minute exposures). We did not see any noticeable damage on the front and back side of the face masks with eyes and under a light microscope, either (data not shown). Their inner filter layer composed of polypropylene meltblown non-woven fabric was further examined under a SEM. As shown in Figure 2, there was no detectable structural damage caused to the filter layer of the exposed face masks. The result showed that the repeated exposures (5 times) of face masks to ozone gas did cause structural damage to the face masks. 
medRxiv preprint doi: https://doi.org/10.1101/2020.04.26.20080317; this version posted May 5, 2020. The copyright holder for this preprint (which was not certified by peer review) is the author/funder, who has granted medRxiv a license to display the preprint in perpetuity.

\section{Without ozone gas exposure}

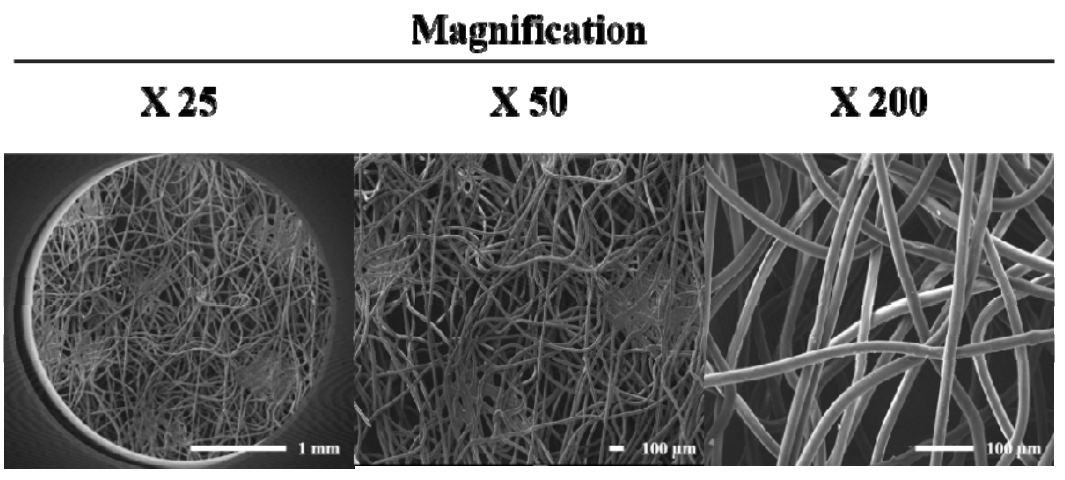

165

166

167

168

169

170

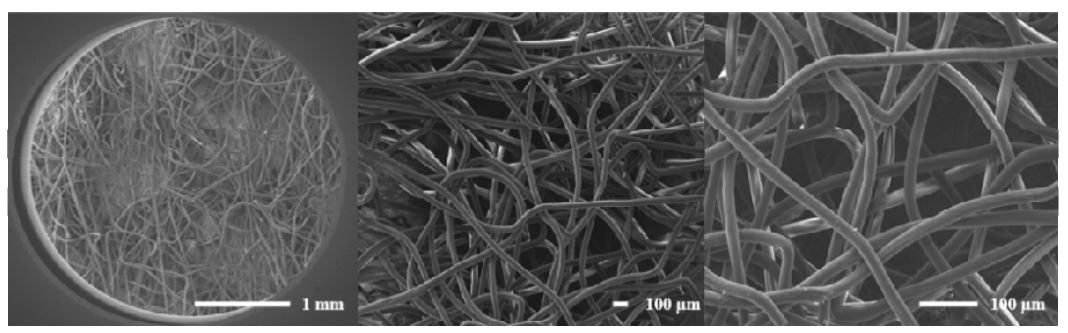

Figure 2. Scanning electron microscopy images of the filter layer of uncontaminated face masks (Kleenguard ${ }^{\circledR}$ ) with and without exposures to ozone gas for 5 min (five 1-minute exposures). The images were taken by a field-emission scanning electron microscope (FESEM-EDS, JSM7500F, JEOL Ltd., Tokyo, Japan).

\section{No functional deterioration on face masks}

The electrocharged filter is an essential component of dust masks such as N95 and KF94 masks and there was a concern that the charge on the filter could be lost with its exposure to ozone gas. The functioning of KF94 masks (registration number: F1-28712011; Kleannara Co., Seoul, Korea) which are certified to filter out $94 \%$ of particulate matter (about $0.4 \mu \mathrm{m}$ diameter), after exposed to ozone gas for $5 \mathrm{~min}$ (five 1-minute exposures) was thus assessed using a standard test for measuring PFE with paraffin oil mists. ${ }^{15}$ There was no statistical difference in PFE between the exposed and unexposed face masks (Table 3). Taken together with the SEM images, it is suggested that the repeated exposures (5 times) of face masks to ozone gas do not cause structural or functional damage to the face masks. 
medRxiv preprint doi: https://doi.org/10.1101/2020.04.26.20080317; this version posted May 5, 2020. The copyright holder for this preprint (which was not certified by peer review) is the author/funder, who has granted medRxiv a license to display the preprint in perpetuity.

All rights reserved. No reuse allowed without permission.

Table 3: PFE of uncontaminated face masks (KF94) with and without exposure to ozone gas.

\begin{tabular}{|c|c|c|}
\hline Certified testing lab & $\begin{array}{c}\text { Ozone gas treatment on } \\
\text { uncontaminated face masks }\end{array}$ & $\begin{array}{c}\text { PFE (\%) } \\
\text { (Mean } \pm \text { S.D.) }\end{array}$ \\
\hline \multirow{2}{*}{$\begin{array}{c}\text { FITI Testing \& } \\
\text { Research Institute }\end{array}$} & None & $98.5 \pm 1.3(\mathrm{n}=3)$ \\
\cline { 2 - 3 } & Ozone gas (120 ppm, 5 min) & $99.3 \pm 1(\mathrm{n}=3)$ \\
\hline $\begin{array}{c}\text { Korea Mask } \\
\text { Laboratory }\end{array}$ & None & $98.4 \pm 0.5(\mathrm{n}=6)$ \\
\cline { 2 - 3 } & Ozone gas (120 ppm, 5 min) & $98.6 \pm 0.5(\mathrm{n}=6)$ \\
\hline
\end{tabular}

a The lab is certified and registered as a testing lab by the ministry of food and drug safety

186 (MFDS) in Korea.

$187{ }^{b}$ Measured by a standard method using paraffin mist. n: sample number.

\section{- CONCLUSIONS}

In this study, using a human coronavirus (HCoV-229E) as a surrogate for SARS-CoV-2

contamination on face masks, the virus is shown to lose its infectivity to a human cell line (MRC-5) when exposed for a short period of time $(1 \mathrm{~min})$ to ozone gas produced by the DBD plasma generator. SEM and PFE tests revealed that there was no structural or functional deterioration observed in the face masks even after they underwent excessive exposure to ozone (five 1-minute exposures).

Ozone gas is a strong oxidizing agent with the ability to kill viruses on hard-to-reach surfaces, including the fabric structure of face masks. Inexpensive consumer-grade ozone generators are widely available. Our results suggest that it may be possible to rapidly disinfect face masks contaminated with SARS-CoV-2 using a plasma generator in a wellventilated place.

\section{MATERIALS AND METHODS}

\section{DBD plasma generator}

204 The plasma generator consists of a high-voltage, high-frequency generator (Minipuls 2.2;

205 GBS Elektronik GmbH, Großerkmannsdorf, Germany) and two electrodes separated by a 1

$206 \mathrm{~mm}$-thick alumina dielectric barrier. Each electrode was made of a perforated stainless-steel 207 plate and bare aluminum tape. The plasma was produced only at the perforated electrode, 208 along the rims of the holes. As the dielectric barrier allows electrons and ions to accumulate 209 on the surface, preventing the transition from a cold plasma to an arc, a sinusoidal voltage 210 was applied to steadily produce the plasma (Figure S2). The plasma was turned on for 1 min 
medRxiv preprint doi: https://doi.org/10.1101/2020.04.26.20080317; this version posted May 5, 2020. The copyright holder for this preprint (which was not certified by peer review) is the author/funder, who has granted medRxiv a license to display the preprint in perpetuity.

All rights reserved. No reuse allowed without permission.

211 after every 4 min to avoid any damage resulting from thermal heating.

\section{UV absorption spectroscopy}

213 The ozone concentrations produced by the DBD plasma generator were measured via UV

214 absorption spectroscopy. ${ }^{16}$ Light from a mercury lamp (BHK 90-0005-01, spectral line: 253.65

$215 \mathrm{~nm}$ ) was collimated using lenses and an optical fiber and sent through a gas medium, $4.3 \mathrm{~cm}$

216 above the electrode surface where the plasma is produced. The transmitted light intensity

217 was then measured using a spectrometer (AvaSpec-2048L). As the wavelength-dependent

218 absorption cross section of ozone is broad near $253.65 \mathrm{~nm}$ and known as $1.137 \cdot 10^{-17}$

$219 \mathrm{~cm}^{2}$ molecule ${ }^{-1}$, the ozone concentration can be evaluated by the Beer-Lambert law 220 described as follows:

$$
n_{O_{3}}=-\frac{1}{\sigma_{O_{3}} L} \ln \left(\frac{I}{I_{0}}\right)
$$

221 where $I$ and $I_{0}$ are the transmitted and incident light intensities; $n_{O 3}$ is the number density of 222 ozone; $\sigma_{O_{3}}$ is the ozone absorption cross-section near $253.65 \mathrm{~nm}$; $L$ is the optical path 223 length. The ozone concentrations under the test conditions were determined to be 224 approximately 120 ppm.

\section{Coronavirus culture}

226 HCoV-229E was cultured using human fetal lung fibroblast cell (MRC-5; ATCC, Bethesda, MD, 227 USA) in a 96-well plate. ${ }^{11}$

\section{Exposure of face masks experimentally contaminated with HCoV-229E to ozone gas}

229 Samples $(n=6)$ were cut $(30 \mathrm{~mm} \times 35 \mathrm{~mm}$ in size) from face masks and sprayed with about $230250 \mu \mathrm{L}$ of HCoV-229E culture (4.5 log $\mathrm{TCID}_{50}$ per $\mathrm{mL}$ ) in a biosafety cabinet at a biosafety 231 level-2 (BSL-2) laboratory while wearing face masks and gloves. The samples were then 232 dried for $15 \mathrm{~min}$ at $25{ }^{\circ} \mathrm{C}$ and were individually exposed to ozone for both 1 and 5 min using 233 the plasma generator (Figure 1) in a chemical hood.

\section{Determination of $\mathrm{TCID}_{50}$ value}

235 Immediately after the exposure, the virus particles on the samples were collected by 236 washing the samples with $5 \mathrm{~mL}$ of PBS (phosphate buffered saline, $\mathrm{pH}$ 7.4). $\mathrm{TCID}_{50}$ was 237 determined by adding serial 10-fold dilutions of HCoV-229E collected from each mask into a 
medRxiv preprint doi: https://doi.org/10.1101/2020.04.26.20080317; this version posted May 5, 2020. The copyright holder for this preprint (which was not certified by peer review) is the author/funder, who has granted medRxiv a license to display the preprint in perpetuity.

All rights reserved. No reuse allowed without permission.

238 human fetal lung fibroblast cell (MRC-5, ATCC, Bethesda, MD, USA) monolayer in a 96-well plate. ${ }^{11}$ The plates were observed for cytopathic effects for 4 days. The viral titer was calculated via the Reed and Munch endpoint method. ${ }^{11}$ Viral titer collected from the face masks was measured using MRC-5 cells (ATCC, Bethesda, MD, USA). ${ }^{11}$

\section{RT-PCR}

Immediately after the exposure, the virus particles on the samples were collected by washing the samples with $5 \mathrm{~mL}$ of PBS. qRT-PCR was performed using StepOne ${ }^{\mathrm{TM}}$ Real-Time PCR system (Applied biosystems, CA, USA) and MG 2 X One Step RT-PCR SYBR ${ }^{\circledR}$ Green Master Mix reagents (Cancer Rop Co Ltd., Seoul, Korea). A segment of the $N$ gene of HCoV229E was amplified using a forward primer (CGCAAGAATTCAGAACCAGAG) and a reverse primer (GGCAGTCAGGTTCTTCAACAA) $^{13}$ with an amplicon size of 83 bp (Bioneer, Daejeon, Korea). The thermocycler conditions were as follows: reverse transcriptase at $50{ }^{\circ} \mathrm{C}$ for $30 \mathrm{~min}$ and an initial denaturation at $95{ }^{\circ} \mathrm{C}$ for $5 \mathrm{~min}$, followed by 45 cycles of denaturation at $95{ }^{\circ} \mathrm{C}$ for $15 \mathrm{~s}$, annealing at $52^{\circ} \mathrm{C}$ for $30 \mathrm{~s}$, and an extension at $72{ }^{\circ} \mathrm{C}$ for $30 \mathrm{~s}$. To confirm that the target amplicon was properly formed, a melting curve analysis was conducted. The fluorescence intensity was measured within the range of $60-95^{\circ} \mathrm{C}$ at a rate of $0.2^{\circ} \mathrm{C} / \mathrm{s}$.

\section{SEM}

A field-emission scanning electron microscope (FE-SEM-EDS, JSM7500F, JEOL Ltd., Tokyo, Japan) was used to take images of untreated and treated masks $(n=4)$. To obtain the morphology of the electrostatic melt blown filter layer, which is the middle layer of the face mask, the melt blown filter was cut to obtain a $5 \mathrm{~mm} \times 5 \mathrm{~mm}$ sample that was coated with iridium (Ir) for 15 minutes via the ion sputtering method. The FE-SEM-EDS was operated at $15 \mathrm{kV}$, and the working distance (WD) was $8 \mathrm{~mm}$. All the sample images were acquired with magnification factors of 25,50 , and 200.

\section{Paraffin Oil Test}

The standard test for measuring the filtration efficiency with paraffin oil mist was performed on masks at FITI Testing \& Research Institute (Cheongju, Korea) and Korea Mask Laboratory (KML; Hanam city, Korea), the authorized testing organizations in Korea. In this test, a tester first produces paraffin oil mist with a particle size ranging from 0.05 to $1.7 \mu \mathrm{m}, 0.4 \mu \mathrm{m}$ on average. ${ }^{15}$ The flow containing the paraffin oil aerosol at a concentration of $20 \pm 5 \mathrm{mg} / \mathrm{m}^{3}$ is 
medRxiv preprint doi: https://doi.org/10.1101/2020.04.26.20080317; this version posted May 5, 2020. The copyright holder for this preprint

(which was not certified by peer review) is the author/funder, who has granted medRxiv a license to display the preprint in perpetuity.

All rights reserved. No reuse allowed without permission.

268 then blown towards the mask at a flow rate of $95 \mathrm{~L} / \mathrm{min}$. The filtration efficiency, given by Eq.

269 (2), is then evaluated by measuring the concentrations of paraffin oil mist upstream and 270 downstream of the mask. The efficiency is a value averaged over $30 \mathrm{~s}$ and must be measured 271 within 3 min after the test starts.

$$
P=\frac{C_{1}-C_{2}}{C_{1}} \times 100
$$

272 where $P$ is the filtration efficiency; $C_{1}$ and $C_{2}$ are the concentrations of paraffin oil mist 273 upstream and downstream of the mask, respectively.

274

275 Supplementary Materials: Supplementary materials can be found at 276 www.mdpi.com/xxx/s1.

277 Acknowledgements: We thank Ms. J. So for giving an idea for the project.

278 Funding: S.P. was supported by the BioNano Health-Guard Research Centre as a Global 279 Frontier Project (H-guard 2018M3A6B2057299) through the National Research Foundation 280 (NRF) of Ministry of Science and ICT (MSIT) in Korea. M.S.B. was supported by a grant 281 through a future integration program of Kangbuk Samsung Hospital-Biomedical Institute for 282 Convergence (BICS) at Sungkyunkwan University.

283 Conflicts of Interest: The authors declare no conflict of interest.

284

285

286

287 


\section{References}

299 1. Leung NHL, Chu DKW, Shiu EYC, et al. Respiratory virus shedding in exhaled breath and efficacy of face masks. Nat Med. 2020. doi:10.1038/s41591-020-0843-2.

301 2. Kumar A, Kasloff SB, Leung A, et al. N95 Mask Decontamination using Standard Hospital Sterilization Technologies. Preprint. Posted online April 08, 2020. MedRxiv. doi:10.1101/2020.04.05.20049346.

$3043 . \quad H u d s o n$ JB, Sharma M, Vimalanathan S. Development of a practical method for using ozone gas as a virus decontaminating agent. Ozone Sci Eng. 2009;31(3):216-223. doi:10.1080/01919510902747969.

4. Zimmermann JL, Dumler K, Shimizu T, et al. Effects of cold atmospheric plasmas on

310 5. Mastanaiah N, Johnson JA, Roy S. Effect of dielectric and liquid on plasma sterilization using dielectric barrier discharge plasma. PLOS One. 2013;8(8):e70840 doi:10.1371/journal.pone.0070840.

6. Morfill GE, Shimizu T, Steffes B, Schmidt HU. Nosocomial infections-a new approach towards preventive medicine using plasmas. New J Phys. 2009;11(11):115019.. coronavirus receptor aminopeptidase N (CD13): influence of $\mathrm{N}$-linked glycosylation. $J$ Virol. 2001;75(20):9741-9752. doi:10.1128/JVI.75.20.9741-9752.2001.

9. Stefanovic I, Bibinov N, Deryugin A, et al. Kinetics of ozone and nitric oxides in dielectric barrier discharges in 02/NOx and N2/O2/NOx mixtures. Plasma Sources Sci Technol. 2001;10(3):406.

324 10. Dotis J, Roilides EJH. H1N1 Influenza A infection. Hippokratia. 2009;13(3):135-138. 
medRxiv preprint doi: https://doi.org/10.1101/2020.04.26.20080317; this version posted May 5, 2020. The copyright holder for this preprint

(which was not certified by peer review) is the author/funder, who has granted medRxiv a license to display the preprint in perpetuity.

All rights reserved. No reuse allowed without permission.

325 11. Reed LJ, Muench H. A simple method of estimating fifty per cent endpoints. Am J

326

327

328

329

330

331

332

333

334

335

336

337

338

339

340 Epidemiol. 1938;27(3):493-497. doi:10.1093/oxfordjournals.aje.a118408.

12. Reuter S, Winter J, Iseni S, et al. Detection of ozone in a $\mathrm{MHz}$ argon plasma bullet jet. Plasma Sources Sci Technol. 2012;21(3):034015.

13. Lu R, Yu X, Wang W, et al. Characterization of human coronavirus etiology in Chinese adults with acute upper respiratory tract infection by real-time RT-PCR assays. PLoS One. 2012;7(6):e38638 doi:10.1371/journal.pone.0038638.

14. Tseng C, Li C. Inactivation of surface viruses by gaseous ozone. J Environ Health. 2008;70(10):56-63.

15. Choi HW, Yoon S, Lee $\mathrm{JH}$, et al. Comparison of pressure drop and filtration efficiency of particulate respirators using welding fumes and sodium chloride. Ann. Occup. Hyg. 2011;55(6):666-680. doi: 10.1093/annhyg/mer032.

16. Orphal J, Staehelin J, Tamminen J, et al. Absorption cross-sections of ozone in the ultraviolet and visible spectral regions: Status report 2015. J Mol Spectrosc. 2016;327:105-121. doi: 10.1016/j.jms.2016.07.007. 